\title{
Games \& Drama Applications in Language Acquisition
}

DOI: $10.26466 /$ opus.881111

$*$

\author{
Murat Demirekin - Hatice Yalçın ** \\ ** Dr., Private Academy BLC English Course \\ E-Mail: mdemirekin@gmail.com \\ ORCID: 000-0001-6757-0487 \\ * Dr. Öğr. Üyesi, KTO Karatay University, Child Development, Konya/Turkey \\ E-Mail hatice.yalcin@karatay.edu.tr \\ ORCID: $\underline{0000-0003-3557-86490}$
}

\begin{abstract}
This research aims to reveal the effects of games and drama practical applications on language acquisition for pre-school children. "Game \& Drama in Language Acquisition" training program has been applied to 4-6-year-old children attending pre-school educational institutions, and the results were analyzed respectively. The study comprises 126 volunteering parents and 126 children attending preschool institutions. At the same time, 32 teachers have evaluated the activities. The content of the training program includes modules with game \& drama activities that aim to strengthen language acquisition in pre-school children. Data collection tools were the Vocabulary Performance Checklist to analyze the concepts and words acquired by children; Identification Scale of Preschool Teachers' Opinions on Game Activities to reveal the parents' views. In the data analysis, in order to determine the differences of the answers reported by the experimental and control groups in the pre-test and post-test, analyzes were performed for independent groups using $t$-test, variance analysis, and Mann Whitney $U$ test. The statistical results of the data have revealed that games and drama activities supporting language acquisition increase the level of effectiveness significantly when applied together with parental training and that using games and drama in the preschool period is an effective method for the children's development of self-expression and language using skills consciously.
\end{abstract}

Keywords: Language acquisition, preschool children, games, drama, vocabulary test 


\section{Dil Ediniminde Oyun ve Drama Uygulamaları}

\section{Öz}

Bu araştırmada amaç; okul öncesi dönemdeki çocuklara dil edinimi sağlanmasında oyun ve drama uygulamalarının etkisinin değerlendirilmesidir. Okul öncesi eğitim kurumlarına devam eden 4-6 yaş çocuklara "Dil Ediniminde Oyun ve Drama" eğitim programı uygulanmış ve sonuçları değerlendirilmiştir. İki okul öncesi eğitim kurumundaki ebeveynler arasından araştırmaya katılmaya gönüllü olan 126 ebeveyn ve 126 çocuk çalışma kapsamına dahil edilmiştir. Aynı zamanda etkinlikleri 32 öğretmen de değerlendirmiştir. Eğitim programının içeriğinde okul öncesi dönemdeki çocuklarda dil edinimini güçlendiren oyun ve drama etkinliklerini içeren modüller bulunmaktadır. Veri toplama aracı olarak Kişisel Bilgi Formu, çocukların edindikleri kavram ve kelimeleri değerlendirmek amactyla Kelime Performans Kontrol Listesi; öğretmen görüşlerini değerlendirmek amactyla Okul Öncesi Öğretmenlerinin Oyun Etkinliklerine İlişkin Görüş Belirleme Ölçeği kullanılmıştır. Veri analizinde deney ve kontrol grubunun öntest ve sonteste verdikleri cevaplarm gruplara göre farklılı̆̆ın belirlemek amacıyla bağımsız gruplar için $t$ testi, varyans analizi ve Mann Whitney $U$ testi ile analizler yapılmıştır. Araştırma sonucunda elde edilen verilerin istatistiksel sonuçlarl, dil edinimini destekleyen oyun ve drama etkinliklerinin, ebeveyn eğitimleri ile birlikte uygulanması durumunda etkililik düzeyini anlaml derecede artırdığını, okul öncesi dönemde oyun ve dramanın çocukta kendini ifade etme ve dili bilinçli kullanma becerilerinin geliştirilmesinde etkili bir yöntem olduğunu ortaya koymuştur.

Anahtar Kelimeler: Dil edinimi, okul öncesi dönemde çocuk, oyun, drama, kelime testi 


\section{Introduction}

Drama is a type of activity where an individual is asked to depict himself/herself or another person in an imaginary situation (Khan, 2019). Okvuran (2002) defines drama as an activity based on "role-playing" and states it as an entertaining method in which the individual projects a situation in all its details. A game is an important means of communication that enables children to comprehend the world, to interact with other children, to control and express their emotions, and to develop symbolic representation skills (Yalçın, 2010). On the other hand, the main aim of drama is to develop language, communication, and empathy skills. The game \& drama education given from an early age provides great benefits in terms of gaining naturalness and language skills to a child (Cunico, 207). The drama method is a process-oriented teaching technique that allows children to express themselves freely without the fear of making mistakes (Lee, Patall, Cawthon and Steingut, 2015). In addition, the information learned through fun and drama tends to be permanent. Especially when children use their bodies and minds, they seem to learn more effectively and permanently. Using games and drama is also an important learning tool in this respect (Andersen, 2004). O'Hara (1984) points out that the drama method should be preferred among teaching methods due to its relaxing feature. Metinnam (2019) emphasizes that the "inability to express oneself", which lies behind most failures in the language and social development process, can be overcome with the game \& drama method. Aydın (2019) underlines that the drama method is an important strategy in language development, that it has benefits such as self-confidence when speaking, fluent speaking, increasing vocabulary, expressing thoughts, improving communicative skills, using language in different situations, defining, discussing, and evaluating the relevant skills.

Considering the drama applications in Turkey, the concepts "show, roleplaying, improvisation, bazaars, theater" were regarded in the same sense prior to the 1980 (Adigüzel, 2017). In 1926, stage shows called as "dramatization" were performed in the form of sketch, song, theater, and stage performance as a teaching method in primary school programs. After 1980, drama method began to be used in language teaching in universities within the academic scope (Aydin, 2019). After this period, which was considered as the beginning of the contemporary sense of drama practices in Turkey, creative 
drama, psychodrama, educational drama and socio-drama applications began to be implemented starting from preschools (Adıgüzel, 2017).

Underlining the benefits of games and improvisation methods in language development in pre-school period, Montessori (1966) emphasizes that activities that attract the attention of the child, stimulate and make them 'meaningful' for the child, provide permanent learning, as well as the fact that such a method in language teaching is important in using language purposefully. Language teaching focuses on interaction just like drama. Following different strategies that cover the basic skills of language such as listening, comprehension, speaking, and writing in language teaching strengthen the relevant language acquisition process (Paesani, 2011).

The concept of "language acquisition" is defined as the purposeful, conscious, and appropriate use of language (Andersen, 2004; Tzu-Jung, Justice, Emery, Mashburn \& Pentimonti, 2017). Bloom (1970) points out that activities including game and body movements are quite effective methods in language acquisition. Besides the fact that game \& drama technique is effective in gaining the social relationship, bonding, starting and ending communication skills, it is also influential in strategies to use language correctly, thus it is an effective method that provides language acquisition (Wright, 2006).

As with the use of all language activities, game \& drama activities become more successful when well-prepared and what kind of drama to teach using proper language strategy is well designed accordingly (Genc, 2003). In the use of drama techniques in language teaching, one should consider the relevance of activities to the curriculum, whether there is a feature to increase the awareness of linguistic features, the duration of the lesson, the number of participants, and feasibility in terms of space. Thus, game \& drama technique ensures continuity in learning, and language acquisition takes place respectively (Ozdemir and Ulas, 2017; Vaidyanathan, 1991).

Language acquisition is mainly affected by the learning environments offered to an individual (Hoff, 2003). Participation in interactive language learning activities contributes to the development of children's language skills and also provides benefits in issues such as strengthening communication with their peers (Tzu-Jung, Justice, Emery, Mashburn \& Pentimonti, 2017). Saeid and Eslaminejad (2017) have found that there is a positive relationship between inclusion in the learning process and the acquisition of children's language skills. 
The necessity of developing strategies for teaching individuals language skills in order to achieve language acquisition is emphasized in many studies (Demirekin, 2017; Genc, 2003; Hoff, 2003; Khan, 2019; March, 2019; Paesani, 2014). Strategy development studies for qualified and permanent language acquisition started in the 1970s, and have continued with the investigation of the relationship between the uses of different teaching methods since the 1990s. The Inventory of Language Learning Strategies by Oxford (1990) emphasizes the importance of using applied methods such as games and drama for language acquisition. Permanent learning of the individual in a language acquisition process can be enabled thanks to his/her interactive participation. In this context, it appears that language teaching should be realized using games and drama activities (Demirekin, 2017).

Preschool children tend to be creative and they have distinctive developmental characteristics such as daydreaming and imagining. They frequently experience the need to express their feelings and thoughts; but, because of the limited number of words they know, they have difficulty expressing themselves and try different expressions (Yalçın, 2010). If drama activities are planned systematically and consciously and if appropriate methods are chosen respectively, children's reflecting their rich inner worlds can turn into a better form of expression (Aydin, 2019).

We believe that this study, which is fun and involves parents by using the drama technique, which is a permanent strategy in language acquisition, will draw attention to an important gap to fill in the field of language education for children. While there are many studies on the use of language learning strategies and the factors affecting them, the inadequacy of dream-oriented games and drama studies also seems to be an important gap in this field. Therefore, our study contains outstanding data in terms of getting some knowledge about children's language comprehension and language learning techniques. There are very few studies published on how and to what extent the strategies that children use while learning a language. Our study presents some considerable outcomes regarding method and content, especially in terms of "learning to learn" as well as game and drama. The results of the research present the details of game \& drama techniques to institutions that work on language teaching. In addition, our study includes various data on areas such as child development, psychology, social services, psychological counseling and guidance, family counseling, and language teaching. In our 
study, suggestions are made on the introduction of game \& drama techniques that can be used with preschool children and their parents, as well as focusing on "permanent language learning". In addition, the research findings will contribute to the development of theories, methods and techniques in the field of child education and language teaching by enabling researchers and educators to recognize the characteristics of language learners.

In this study, we have aimed to reveal the effects of games and drama practices that provide language acquisition to preschool children. Within the framework of this main objective, we have examined whether the study group differentiated according to socio-demographic variables, and thus we have sought to answer the following research questions:

- Are pre-school children's attitude scores towards creative drama after game \& drama applications significantly different from their previous attitude scores?

- Do pre-school children's attitude scores towards creative drama after game \& drama practices differ significantly in terms of demographic characteristics?

- Is there a significant difference between the opinions of parents with the children in pre-school period about a training program that supports language acquisition and their demographic variables?

\section{Method}

\section{Aim}

The aim of this research is to reveal the effects of games and drama practices that provide language acquisition for preschool children.

"Game \& drama for Language Acquisition" (GDLA) training program was applied to 4-6-year-old children attending pre-school education institutions, and the findings were assessed by receiving the opinions of teachers and parents. The content of this training program includes modules that support language development in preschool children besides games and drama activities focusing on daydreaming which is supposed to improve verbal and non-verbal expression skills. 


\section{Research Design}

This study was carried out as an experimental design; in this context, experimental and control groups were used in the research. The compliance of the study with ethical rules was approved by the KTO Karatay University Medical Device Ethics Committee with the decision number 2021-049 and the board decision dated 12.01.2021. While a training supporting language acquisition through game \& drama was provided to the experimental group, the control group was given a formal training in accordance with the routine curriculum as in all schools. Studies conducted with the experimental design are considered as the ones in which the most accurate results can be obtained among scientific methods. Comparable processes are implemented, and then the effects of these processes are investigated in such a design (Merriam, 2013). The "Vocabulary Performance Checklist (VPCL)" and "Identification Scale of Preschool Teachers' Opinions on Game Activities (ISPTOGA)" applied to children in the experimental group constitute the quantitative dimension of the study.

This research is also a descriptive study based on qualitative analysis that includes parents' and teachers' views on game \& drama training that support language acquisition, and the "case study design" (McMillan \& Schumacher, 2010) has been used accordingly. The basic characteristic of qualitative case studies is the in-depth investigation of different situations (Yuldırım \& Şimşek, 2013). In this study, teachers' evaluations were taken to reveal the situation, and at the same time, parents were asked to report their opinions to the school once each module was completed.

When forming the study group, "easily accessible situation sampling" was used, which is among purposeful sampling methods. Two kindergartens close to the university campus were selected due to the fact that the sample group of the kindergartens where the study was conducted seemed suitable for the research purposes and the positive relations established with the teachers and administrators of the schools in terms of ease of the study. In the easily accessible case sampling method, the researcher chooses a study group that is easy to reach. This method provides speed and practicality to the research process (Yıldırım \& Şimşek, 2013). Table 1 presents the research design applied to the children in the study group. 
Table 1. Research Design

\begin{tabular}{llll}
\hline Group & Pretest & Application & Posttest \\
\hline Experimental & Vocabulary & Game \& Drama for & Vocabulary Performance \\
& Performance Checklist & Language Acquisition & Checklist \\
\hline Control & Vocabulary & Routine educational & Vocabulary Performance \\
& Performance Checklist & system practices & Checklist \\
\hline
\end{tabular}

\section{Study Group}

After obtaining the necessary permissions from two different pre-school education institutions where the research would be conducted, detailed information was given about the modules of Game \& Drama in Language Acquisition in the meetings held with parents. 126 parents and 126 children, who volunteered to participate in the research upon reading the text containing meeting information given to the institutions, were included in the study.

Within the scope of this study, teachers' opinions were also received to determine the activities carried out, and 32 teachers who volunteered to evaluate the study were included in the study group. Table 2a shows the demographic characteristics of the children in the study group.

Table 2a. Demographic Characteristics of Participant Children $(N=126)$ and Parents $(N=$ 126)

\begin{tabular}{llll}
\hline Socio-demographic variables & & $\mathbf{n}$ & $\mathbf{\%}$ \\
\hline Age & 4 & 37 & 29.3 \\
& 5 & 49 & 38.8 \\
& 6 & 40 & 31.7 \\
\hline Gender & Female & 61 & 48.4 \\
& Male & 65 & 51.5 \\
\hline Number of siblings & Only child & 41 & 32.5 \\
& 2 siblings & 49 & 38.8 \\
& 3 and more siblings & 36 & 28.5 \\
\hline Mother's educational status & Primary school & 65 & 51.5 \\
& High school graduate & 37 & 29.3 \\
& University graduate & 24 & 19 \\
\hline Father's educational status & Primary school & 21 & 16.6 \\
& High school graduate & 62 & 49.2 \\
& University graduate & 43 & 34.1 \\
\hline
\end{tabular}

$38.8 \%$ of the children in the study group were 5 years old, $51.5 \%$ of them were boys. $38.8 \%$ of them were two siblings. $51.5 \%$ of the mothers participating in the study were primary school graduates, $49.2 \%$ of the fathers were high school graduates. Table $2 \mathrm{~b}$ illustrates the socio-demographic characteristics of the teachers in the research group. 
Table 2b. Demographic Characteristics of the Teachers in the Study Group

\begin{tabular}{llll}
\hline Teacher's Age & Younger than 25 & 11 & 34.3 \\
& 26-35 & 14 & 43.7 \\
& Older than 36 & 7 & 21.8 \\
\hline Teacher's graduation status & High school & 5 & 15.6 \\
& Associate Degree & 14 & 43.7 \\
& University graduate & 13 & 40.6 \\
\hline Teacher's status of receiving lan- & Received & 4 & 12.5 \\
guage development training & Partially received & 7 & 21.8 \\
& Not received & 21 & 65.6 \\
\hline
\end{tabular}

$43.7 \%$ of the teachers in the pre-school education institution participating in the study were between the ages of $26-35 ; 43.7 \%$ of them were associate degree graduates, and $65.6 \%$ did not receive a training program that supports language acquisition for children in pre-school period after graduation.

\section{Data Collection Tools}

The following have been used as data collection tools: Personal Information Form to identify the participants; Vocabulary Performance Checklist (VPCL) to analyze the concepts and words acquired by children; Identification Scale of Preschool Teachers' Opinions on Game Activities (ISPTOGA) has been used to reveal the parents' views.

Personal Information Form: It includes questions about the age, gender, number of siblings, educational levels of the mother and father, and whether or not they have received drama education before.

Vocabulary Performance Checklist (VPCL): It contains a list of the concepts and words that preschool children are expected to acquire. The teaching method of Frankel and Wallen (2006) regarding research design and evaluation in training was taken as basis in the study: Thus, the evaluation criteria were created by the researchers based on the data with the aspects such as learning materials, questions to be asked to the participants, and then the relevant list was prepared accordingly. Their method is an easy-to-apply, fast, and functional tool that clearly measures learning status in terms of language acquisition. In mother tongue or a second language teaching, concepts are asked together with visuals and 1 point is given to each word known successfully. Words consist of concepts and objects suitable for children's understanding and learning process. Words that are related to the environment and 
real lives of preschool children such as parts of the body, concepts of place or direction, emotions, objects, animals, etc. are added to the list. In order to avoid scoring or grading stress, it is recommended to note the child's answer in a way that the child cannot see the commenting as "true or false". Children are taken into a different room one by one, and the application is realized by asking for concepts in the form of color images in the typical A4 size paper. You had better set aside 10 to 15 minutes to spend with each child. For example, they are asked to select the butterfly among a few visuals, and 1 point is given if the answer is correct after waiting 10 seconds. A maximum grade of 33 marks is earned from the test.

Identification Scale of Preschool Teachers' Opinions on Game Activities (ISPTOGA): Developed by Dilekmen and Bozan Tüzün (2018), the scale includes 14 items with the adults' views on the role of games in education and training in preschool children. The form was applied to preschool teachers, then item and factor analysis were performed respectively. The data obtained from the validity and reliability analysis of the scale showed that the scale had three sub-dimensions: "effect of games on learning", "effect of games on development", and "effect of games on practice". In this study, the Cronbach Alpha value, which was performed to measure the reliability of the scale, was found as .86 .

\section{Process \& Data Analysis}

After the Ethics Committee and official permissions were obtained for the applications to be carried out within the scope of the study, two different preschool institution administrators were interviewed, and detailed information was offered to the parents and teachers in a meeting attended by the parents as well. Volunteering parents, children, and teachers were included in the study. The Vocabulary Performance Checklist was administered to the children in the study group as a pretest, followed by an eight-week training program of Game \& Drama for Language Acquisition (GDLA) training program. The training programs were carried out twice a week and in the form of activities lasting 30 minutes each time. At the end of the process, evaluations were made upon the applications of the Vocabulary Performance Checklist to the children as a posttest again and the ISPTOGA as a posttest to the teachers respectively. 
One of the schools was determined as the experimental group $(n=61)$ and the other as the control group $(n=65)$, and within the scope of the study, games \& drama activities supporting language acquisition were prepared for the children in the experimental group. Active participation of children was encouraged in these activities. For instance, firstly, acquaintance activities were held to get to know the researchers, and the role-playing behaviors in which the children introduced themselves by imitating their family members were supported and encouraged accordingly. Pictures of different professions, foods, or items were shown, and then the children were asked to describe them and revive their memories about these images. The daily life memory regarding a mole was described with the narrator's intense body language and a puppet. By showing the pictures of a mole, some information was given about how they live, their species, and physical characteristics; besides, children wearing mole masks were allowed to have an improvised conversation with other children, and their questions were answered accordingly. To reinforce, the children painted the mole drawings; then, more drawings of the moles to paint were given as homework. They were set on improvising the imitation behaviors related to the life of a mole in nature. A story was told by showing the children some pictures. After that, the children were asked to act out the story, we made sure that the participation of the whole class and actively talking of all the children. Occasionally, activities were carried out to facilitate them to learn new words through imagination. All children were asked to close their eyes and imagine that they were playing with their favorite friend in a messy room and that they lost their toys among their belongings due to the mess. The children were given time to think, and after opening their eyes, they were asked to express the thoughts they envisioned in their minds. In each module, drama activities were held such as "little pink soap", "the tree that goes out for a walk", "the friends of the elephant with a red trunk", "Keloğlan and Nasreddin's balloon trip".

These activities were implemented with the children in the institution, and they were asked to do the same activities with their parents at home. Every week, feedback notes were taken from the parents who express their opinions about these games, and once the module training was completed, the Identification Scale of Preschool Teachers' Opinions on Game Activities was applied to the participant teachers. Drama activities lasted 8 weeks. 
In the study, frequency and percentage analysis were performed by using descriptive statistical methods. The data were assessed by using one-way analysis of variance (ANOVA) and Pearson correlation coefficient via SPSS 26.0 package program. In the data analysis, a t-test was conducted for independent groups in order to determine the difference between the answers given by the experimental and control groups regarding the pre and posttests. In these analyzes, the significance level was considered as 05 . Alpha values were calculated for the reliability of the pre and posttests. The alpha value of the internal consistency coefficient for the reliability analysis of the VPCL applied for pretest and posttest was revealed as .79, and the alpha value of the ISPTOGA was .86. This study also included real reporting statements of participating parents to enrich the findings.

\section{Results}

The data obtained in the study are given in a table. Table 3 contains data on the comparison of the VPCL pre-test mean scores of the children in the experimental and control groups.

Table 3. Comparison of VPCL Pre-Test Scores of Experimental and Control Groups

\begin{tabular}{|c|c|c|c|c|c|c|}
\hline Group & $\mathrm{N}$ & $\bar{x}$ & $\mathrm{~s}$ & SD & $\mathrm{t}$ & $\mathrm{p}$ \\
\hline Experimental & 61 & 23.36 & 11.538 & 124 & .624 & .548 \\
\hline Control & 65 & 24.62 & 12.636 & & & \\
\hline
\end{tabular}

Table 3 revealed that there was no significant difference $(p>0.05)$ between the pre-test average scores of the experimental group and the control group $(\mathrm{t}=0.624 ; \mathrm{p}=.548)$. The pre-test average of the experimental group was $\overline{\mathrm{x}}=$ 23.36 , and the average of the pre-test scores of the control group was $\bar{x}=24.62$. VPCL pretest results showed that both groups were successful at a good level; the experimental and control groups were at a similar success level before the research; thus we may claim that the applications have started with the similar characteristics of these two groups. The data regarding the comparison of the VPCL posttest average scores of the children in the experimental and control groups are shown in Table 4. 
Table 4. Comparison of VPCL post-test mean scores of the experimental and control groups

\begin{tabular}{lllllll}
\hline Group & $\mathrm{N}$ & $\overline{\mathrm{x}}$ & $\mathrm{s}$ & $\mathrm{SD}$ & $\mathrm{t}$ & $\mathrm{p}$ \\
\cline { 1 - 5 } Experimental & 61 & 31.84 & 8.425 & 124 & 4.272 & .000 \\
\cline { 1 - 3 } Control & 65 & 25.72 & 7.126 & & & \\
\hline
\end{tabular}

The comparison of the posttest scores of the experimental and control groups in Table 4 revealed that there was a significant difference $(\mathrm{p}<0.05)$ between the experimental group and the control group's posttest scores $(t=$ 4.272 and $p=.000$ ). The posttest average score of the experimental group was $\bar{x}=31.84$, and the posttest score average of the control group was $\bar{x}=25.72$. The arithmetic mean of the posttest scores of the experimental group was found to be higher than the scores of the control group. This result shows that a training program that supports language acquisition through game \& drama positively affects success.

We analyzed the opinions of teachers working in preschool institutions about game \& drama activities for language acquisition (GDLA) and investigated whether there was a significant difference in terms of the age variable for the teachers. For this purpose, one-factor analysis of variance-ANOVA was applied, and the relevant findings obtained are presented in Table 5.

Table 5. Variance Analysis Results of the Scale on the Teachers' Opinions about GDLA Program based on the Age Variable $(N=32)$

\begin{tabular}{llllll}
\hline Sub-dimensions of the scale & Age & $\mathrm{n}$ & $\overline{\mathrm{x}}$ & $\mathrm{F}$ & $\mathrm{p}$ \\
\hline Effect of the program on learning & Younger than 25 & 11 & 7.23 & & \\
& 26-35 & 14 & 9.02 & 3.262 & $.032^{*}$ \\
& Older than 36 & 7 & 11.84 & & \\
\hline Effect of the program on develop- & Younger than 25 & 11 & 3.15 & & \\
ment & $26-35$ & 14 & 3.08 & 3.724 & .028 \\
& Older than 36 & 7 & 4.26 & & \\
\hline Effect of the program on practice & Younger than 25 & 11 & 6.72 & & \multirow{2}{*}{.730} \\
& 26-35 & 14 & 5.88 & .282 & \\
& Older than 36 & 7 & 6.36 & & \\
\hline
\end{tabular}

We have determined that ISPTOGA is included in the "Effect of the program on learning" sub-dimension, and there was a significant difference (F32 $=3.262$ and $p<0.05$ ) in favor of the teachers over the age of 26 . There was also an outcome referring to in the sub-dimension of "the effect of the program on development", and a significant difference (F32 $=3.724$ and $\mathrm{p}<0.05)$ was 
found to the detriment of the teachers over 36 years old. There was no significant differentiation found in the "effect of the program on practice" sub-dimension $(\mathrm{F} 32=.282$ and $\mathrm{p}>0.05)$. We investigated whether there was a significant difference in terms of teachers' opinions about the GDLA program according to their graduation status, and the results are illustrated in Table 6.

Table 6. Mann Whitney U Test Analysis Results of the Scale on the Teachers' Opinions about GDLA Program Based on Their Graduation Status $(N=32)$

\begin{tabular}{lllllll}
\hline $\begin{array}{l}\text { Sub-dimensions } \\
\text { of the scale }\end{array}$ & $\begin{array}{l}\text { Graduation } \\
\text { Status }\end{array}$ & $\mathbf{N}$ & $\begin{array}{l}\text { Mean } \\
\text { Rank }\end{array}$ & $\begin{array}{l}\text { Sum of } \\
\text { Ranks }\end{array}$ & $\mathbf{U}$ & $\mathbf{p}$ \\
\hline Effect of the & High school & 5 & 8.04 & 7236.5 & & \\
program on & Associate degree & 14 & 11.26 & 9826.5 & 630.5 & .580 \\
learning & University & 13 & 9.36 & 8012.5 & & \\
\hline Effect of the & High school & 5 & 6.12 & 763.5 & & \\
program on & Associate degree & 14 & 7.65 & 1124.5 & 672.5 & .268 \\
development & University & 13 & 9.02 & 1016.5 & & \\
\hline Effect of the & High school & 5 & 5.16 & 1124.5 & & \\
program on & Associate degree & 14 & 7.18 & 7812.5 & 626.5 & .282 \\
practice & University & 13 & 6.42 & 6278.5 & & \\
\hline
\end{tabular}

Regarding the graduation status of teachers, there was no significant difference in terms of the three sub-dimensions of "the effect of the GDLA program on learning, development and practice" in the scale. Therefore, we may state that there is no significant difference found between the graduation status of teachers and their opinions on games \& drama activities that support language acquisition.

Within the scope of the research, a weekly fact sheet was sent to the parents about the training given to the children, and they were asked to report their opinions after each module. Some of the parents' opinions were as follows:

- E7: "My daughter is usually shy. She feels excited and has difficulty in speaking in which we conducted in crowd. But since she was given the task of doing what she had done that day when she came from school, she taught us games after each training, and asked us to repeat the new words she learned. She even started talking to our guests who came to the house, her vocabulary improved considerably."

- E21: "My son is never willing to share because he is an only child. Now he shares his own stuff and toys with his cousins, even this improvement is important to us." 
- E28: "Coming from work, my husband always said that he was tired, and then he spent a long time in front of the television. Now he tends to play games with my son. Recently, they have involved even their old grandfather in the game. The sentences that my son told have become a source of joy for our home."

- E41: "They taught poetry at school. While I was taking my son to school, he made us memorize the poem. Now it's time to learn new songs. Thanks to the school training, we started to do things we had never experienced in our childhood.

- E63: "My daughter has an imaginary friend. She talks to her. While teaching games at school, she narrates whatever teachers exactly say to her imaginary friend. In this way, we find out how and what is taught at school."

- E84: "I don't usually sing, my voice is very bad. But I have a lot of fun singing with my daughter."

- E87: "I don't understand why it only takes eight weeks. Children love these games. Why aren't such activities held until the end of the school year?"

- E101: "I and my wife are teachers. We never express some words at home. My son uses conjunctions and adjectives so meaningfully at home that even the students in my high school cannot use such words in this way. We are very surprised, and we are proud of our son."

- E106: "My daughter said, you performed a play called 'A tree that likes to travel'. My daughter came home crying today. You matched her with the friend $N$, she had a fight before, as pairs, and the "two played the tulip flower role. It seems my daughter cried, but you didn't stop the game because she was supposed to get used to teamwork in the game."

- E109: "We no longer speak slang or offensive words when speaking at home because our kid S. immediately warns us. He corrects us if we say the word wrong. We look as if we were taking a diction lesson. The little boy has turned into a teacher who corrects our speech."

\section{Discussion and Conclusion}

The findings of the research revealed that the training program supporting language acquisition applied to the experimental group was successful, and the arithmetic mean of the posttest scores was higher than the scores of the control group. This result shows that a training program through games and drama increases the success of language acquisition in children. The analysis we conducted within the scope of this research indicates that there is an increasing 
interest in the use of game \& drama method in language learning, and that the game \& drama method is particularly effective in the development of children's communicative skills.

The Vocabulary Performance Checklist pre-test results applied to the experimental and control groups before the training program manifest that the arithmetic means of both groups are close to each other. Thus, language development and vocabulary levels of children in both groups appeared to be similar before the training.

A significant difference has been detected between the pre-test and post-test results of the experimental group and the game \& drama technique, which supports language acquisition in the institution where preschool children are educated, and also provides parental participation. The reason for this difference lies in the fact that applied expressions such as game \& drama bring about active and permanent learning in children, have positive contributions to language acquisition, increasing the number of words as well as the permanence of knowledge. This result seems to be in line with the findings of many studies conducted on preschool children through game \& drama (Adiguzel, 2017; Andersen, 2004; Batd1 \& Batd1, 2015; Genc, 2003; Karadag, 2007; Kuzucu, 2018; Lee, Patall, Cawthon \& Steingut, 2015; Ozdemir \& Ulas, 2017). Those who lack vocabulary will also have difficulty in learning new information as they will have difficulty understanding language (Cunico, 2007). One can learn new information with different learning styles (Demirekin, 2017). Especially at an early age, once activities attracting the attention of children and arouse curiosity are presented, they tend to learn more permanently (Vaidyanathan, 1991). Having examined the drama method in course curriculum content, O'Hara (1984) emphasizes that the more rich materials used in vocabulary teaching, the more permanently children can learn.

In our study, the results of the scale regarding the teachers' opinions about the curriculum revealed that the scale averages of the preschool teachers did not differ significantly according to the graduation status variable. These findings suggest that teachers' views on pre-school game \& drama were not different regardless of their graduation levels. In this study, the teachers over the age of 26 reported on the positive effects of the program on training ( $F 32=3.724$ and $\mathrm{p}<0.05$ ). Therefore, we may assume that the teachers are conscious about the development process and language acquisition of children, which is an expected result, since teachers working in pre-school institutions have provided 
with enough space for the children. Teaching words with the gasification method called "taboo", Hulu (2019) has found that the content, materials and structure of the taboo game are extremely effective in attracting students with different characteristics and increasing their success levels.

There are many studies showing that game \& drama method supports children's developmental areas. Alton (2019) has investigated the effect of drama in language teaching to improve communication and pointed out that when traditional methods are used, students feel bored, distracted, only the students with a better mood at that time remain active in the classroom, but the majority of students are distracted quite often. Premkumar, Vinod, and Sathishkumar (2018), in their study investigating the readiness of medical students to learn, have stated that teacher-centered learning bores, pacifies and limits students, however applying teaching techniques such as drama provide motivation for learning. Examining the relationship between learning and achievement, Saeid \& Eslaminejad (2018) underlines that information is conveyed instantly when participating in practice; and in the drama method, the individual accesses information through his/her real-life experiences. Greveson and Spencer (2005), in their study investigating self-learning and concept teaching, have pointed out that the improvisation method provides permanent learning in dramatizing the plot of an event; They explain that activities that stimulate the senses such as touching, seeing, hearing, and tasting within the scope of drama must be used as teaching techniques. Brits, Potgieter, \& Potgieter (2014), in their research on the use of puppet shows, have found that organizing games using puppets has effects on self-knowledge and concretizing life experiences. Batd1 \& Batdı (2015) have conducted game \& drama activities by asking reminder closed-ended questions to reinforce language acquisition, and determined an increase in children's language development levels. Demircioğlu (2008) investigated the effect of drama while teaching children vocabulary through drama. The study has revealed that drama method positively affects children's vocabulary in language teaching in accordance with the scores obtained from the exams used in analytical thinking skills. Galante \& Thomson (2017) created a drama-based language training program, comparing the development of verbal skills between control and experimental groups. At the end of the study, they observed that the children in the drama-based language training program came up with significant differences in their fluent speech compared to the control group. Kuimoval, Uzunboylu, Startseval, \& Devyatoval (2016) highlighted 
the benefits of drama activities in language teaching and found that not only language learning, but also the culture, moral values, attitudes and behaviors of that language are obtained in the relevant process. Ozdemir and Ulas (2017), in their study on the use of drama as a method in teaching Turkish as a mother tongue, also stressed on the feelings of the participants while reflecting Turkish figures through drama. In the study, they investigated the groups who performed role playing Nasreddin Hodja, Keloğlan, and Karacaoğlan, who were the famous figures among important genres of Turkish folk literature. While performing as a real-life experience, the participants reported that they did not wonder who these roles were or what they were doing; however they seemed to have found out more about Karacoğlan; for example, while dramatizing Karacaoğlan, they were curious about him, and such impulse led to gettting further information about the Karacaoğlan figure. In this case, we may state that curiosity is the priority in language learning, and the drama method imposes such feelings on children.

Teaching languages also refers to teaching the culture of the relevant native speakers. The use of the drama method in language teaching is useful in explaining the similarities between cultures and the differences reflected in language use (Khan, 2019). Starting from preschool period, drama in training has the potential to achieve desired objectives in developing communicative skills. Drama is based on real life conversations; therefore, it allows children to practice language for real purposes (San, 2006). In the study in which drama activity plans applied in pre-school education were examined in terms of various variables, Türkmen (2018); investigated the results related to the formal characteristics of drama activities and revealed that the most integrated activity with drama was Turkish language learning activities. The results of the Vocabulary Performance Checklist used as an assessment tool in our study also reveal the same findings.

In our study, the objectives in the curriculum supporting the field of language development for preschool children were taken as a basis while organizing game \& drama practices. The aims and objectives in the field of language development in early childhood intend to develop the skills of children to understand, speak, and use the relevant language properly. The results of the activities applied in this study show that such gains have been achieved. 
The statistical results of the data obtained in the research revealed that game \& drama activities that support language acquisition increase the level of effectiveness significantly when applied together with parental training, and that game \& drama practice in the preschool period is an effective method for the development of self-expression and language conscious use skills in children. We have found that none of the parents in the study group had a negative perception of the game \& drama method, that drama supports all development areas of preschool children, but is the most beneficial in language acquisition and social development, and brings about the creativity skills for the participants.

Once this study, which supports active participation employing game \& drama, is considered as group work, these activities seem to contribute to the children's cooperation and positive communication with each other. Furthermore, with the activities to increase their vocabulary, the children have developed the ability to talk in front of the community, and they have gained the skills of making quick decisions and expressing different words while explaining the words in different ways. Both parents and teachers stated that children's interest and motivation for learning and finding out new words increased, and their kids tried to learn new words outside of the lesson as well.

\section{Suggestions}

It is important to carry out comprehensive studies on game \& drama technique in order to design individual language teaching processes properly. Language activities focusing on role-playing are useful in language teaching as they involve in real-world scenarios that enable children to learn skills such as collaboration, debate, and teamwork. The application of these skills in real-life situations motivates children to use a language for real purposes.

The findings of our research have revealed that teaching methods in which the child actively participates should be emphasized instead of traditional teaching methods in which the teacher is active and the child is passive within educational activities in schools. Drama classrooms should be created in schools to use the game \& drama method in a proper way for language acquisition and vocabulary development.

As a result of the study, we have observed that the drama method has positively affected not only language acquisition but also motivation and social 
skills in children. According to the findings, it is recommended that those working in the field of education in the early childhood period use game \& drama methods so as to support language acquisition processes.

\section{Kaynakça / References}

Adiguzel, O. (2017). Eğitimde yaratıı drama (10. Baski) Ankara: Pegem Akademi Yayin. Altun, M. (2019). Drama: a neglected source in language teaching to improve communication, International Journal of English Linguistics; 9(5), 242-253. Doi:10.5539/ijel.v9n5p242

Andersen, C. (2004). Learning in "as-if" worlds: Cognition in drama in education. Theory into Practice, 43(4), 268-274. Doi: 10.1207/s15430421tip4304_6

Aydin, G. (2019), Drama yoluyla okul öncesi dönemde İngilizce dil eğitimi, Yüksek lisans tezi, Gazi Üniversitesi Eğitim Bilimleri Enstütüsü Drama ve Eğitimi Ana Bilim Dalı. Ankara.

Batd, V. and Batdl, H. (2015). Effect of creative drama on academic achievement: A metaanalytic and thematic analysis. Kuram ve Uygulamada Egitim Bilimleri, 15(6), 14591470. Doi:10.12738/estp.2015.6.0156

Bloom, L.M. (1970). Language development, form and function in emerging grammars. Cambridge, MA: M.I.T. Press.

Brits, J. S., Potgieter, A. and Potgieter, M.J. (2014). Exploring the use of puppet shows in presenting nanotechnology lessons in early childhood education. International Journal for Cross-Disciplinary Subjects in Education (IJCDSE), 5(4), 1798-1803.

Cunico, S. (2007). Teaching language and intercultural competence through drama: Some suggestions for a neglected resource. The Language Learning Journal, 31(1), 21-29. Doi:10.1080/09571730585200051

Demirekin, M. (2017). Yabancı dil olarak Türkçenin anlamlandırlmasında kelime ve dil öğrenme stratejileri kullanımı. Doktora tezi, Hacettepe Üniversitesi Türkiyat Araştrrmaları Enstitüsü Türkiyat Araştırmaları Anabilim Dalı Yabanc Dil Olarak Türkçe Öğretimi. Ankara.

Fraenkel, J.R. and Wallen, N.E. (2006). How to design and evaluate research in education (Sixth edition). Boston: McGraw-Hill Pub.

Genc, H., (2003). Yabanc dil öğretiminde öğretim tekniği olarak dramanın kullanımı ve bir örnek. Atatürk Üniversitesi Kazım Karabekir Eŏitim Fakültesi Dergisi (Güzel Sanatlar Ĕ̈̆itimi Özel Sayl), 8(1), 267-276.

Greveson, G.C. \& Spencer, J.A. (2005). Self-directed learning-the importance of concepts and contexts. Medical Education, 39(1), 348-349. Doi:10.1111/j.13652929.2005.02115 
Hoff, E. (2003). The specificity of environmental influence: Socioeconomic status affects early vocabulary development via maternal speech. Child Development, 74(1), 1368-1378.

Karadag, E. (2007). Öğrenme kuramlan ve drama yöntemi ilişkisi. Çă̆daş Eğitim Dergisi, $338(1), 39-44$.

Khan, M.O. (2019), Counteractive measures for the tribulations faced by intermediate students of selected colleges of lucknow, while teaching and learning English. Journal of Language Teaching and Research, 10(3), 516-527. Doi:10.17507/j1tr.1003.15

Kuzucu, F.B. (2018). Okul öncesi eŏitime devam eden 48-60 aylik çocuklarm İngilizce dil ediniminde fiziksel aktiviteler ile birleştirilmiş İngilizce müzik ve müzikli oyunlarn etkisi. Yüksek lisans tezi, Yıldız Teknik Üniversitesi. İstanbul.

Lee, B.K., Patall, E.A., Cawthon, S.W. and Steingut, R.R. (2015). The effect of drama-based pedagogy on preK-16 outcomes: A meta-analysis of research from 1985 to 2012. Review of Educational Research, 85(1), 3-49. Doi:10.3102/0034654314540477

Mart, C. T. (2019). Reflections on discussions of literature: A language learning environment to promote speaking skills. The Journal of Social Sciences Research, 5(4), 846850. Doi:10.32861/jssr.54.846.850

Mcmillan, J. H., and Schumacher, S. (2010). Research in education: evidence-based inquiry. (7th ed.). New York: Pearson Publishing.

Merriam, S.B. (2013). Nitel araştırma: Desen ve uygulama için bir rehber (3. Baskıdan Çeviri, Çeviri Editörü: S. Turan). Ankara: Nobel Yayın Dağıtım.

Metinnam, İ. (2019). Sınıf öğretmenliği adaylarının yaratıc drama oturumu planlama sürecinde yaşadıkları sorunların incelenmesi, Yaratıcı Drama Dergisi, 14(2), 219-242.

Montessori, M. (1966). The discovery of child. Adyar, India: Kalakshetra Publications.

O'Hara, M. (1984). Drama in education: A curriculum dilemma. Theory into Practice, 23(4), 314-320.

Okvuran, A. (2002). Dramanın öğretimi ve dramaya dayalı öğrenme. Eğitim Bilimleri ve Uygulama, 1(1), 115-131.

Ozdemir, M., Ulas, A.H. (2017), Drama as a method in teaching the mother tongue: the Turkish language case, Modern Journal of Language Teaching Methods, 7(9), 691708.

Paesani, K. (2011). Research in language-literature instruction: Meeting the call for change? Annual Review of Applied Linguistics, 31(1), 161-181. Doi:10.1017/S0267190511000043

Premkumar, K., Vinod, E., and Sathishkumar, S. (2018). Self-directed learning readiness of Indian medical students: A mixed method study. BMC Medical Education, 18(134), 1-10. Doi:10.1186/s12909-018-244-9. 
Saeid, N. and Eslaminejad, T. (2017). Relationship between student's self-directed-learning readiness and academic selfefficacy and achievement motivation in students. International Education Studies, 10(1), 225-232. Doi:10.5539/ies.v10n1p225.

San, İ. (2006). Eğitimde yaratıcı drama. Ankara: Naturel Yayıncllı.

Saxton, M. (2010). Child language acquisition and development. SAGE Publications.

Türkmen, S. (2018). Okul öncesi eğitimde uygulanan drama etkinlik planlarmın çeşitli değ̈işkenler açısından incelenmesi. Yüksek lisans tezi, G.Ü. Eğitim Bilimleri Enstitüsü, Ankara.

Tzu-Jung, L., Justice, L.M., Emery, A.A., Mashburn, A.J. and Pentimonti, J.M. (2017). Impacts of teacher-child managed whole-group language and literacy instruction on the depth of preschoolers' social interaction. Early Education and Development, 28(4), 457-474.

Ulu, A. (2019). Ortaokul 7. stmıflarda oyunlaştırma yöntemi ile kelime öğretimi (örneklem: tabu). Yüksek lisans tezi, Agri İbrahim Cecen Universitesi Turkçe Egitimi Bilim Dali. Agrı.

Uslu, B. (2018). The study of the effect of "life-focused foreign language acquisition program" on preschool children's english learning. Education and Science, 43(195), 7996

Vaidyanathan, R. (1991). Development of forms and functions of negation in the early stages of language acquisition, a study in Tamil. Journal of Child Language, 18(1), 51-66.

Wright, R. P. (2006). Drama education and development of self: my thorreality? Social Psychology and Education, 9(1), 43-65

Yalçı, H. (2010). Çocuk Gelişimi. Ankara: Nobel Yayınalık.

Yıldırım, A. ve Şimşek, H. (2013). Sosyal bilimlerde nitel araştırma yöntemleri (9. Baskı) Ankara: Seçkin Yayınevi.

\section{Kaynakça Bilgisi / Citation Information}

Demirekin, M and Yalçın, H. (2021). Games \& drama applications in language acquisition. OPUS-International Journal of Society Researches, 17(37), 4027-4048. DOI: 10.26466/opus.881111 